SCIREA Journal of Electrical Engineering http://www.scirea.org/journal/DEE

January 31, 2021

Volume 6, Issue 1 February 2021

\title{
Adsorption of lead ions on carbonaceous sorbents of nutshell obtained from secondary raw material
}

\author{
T. Marsagishvili, G. Tatishvili, N. Ananiashvili, N. Giorgadze, Z. Samkharadze, \\ E. Tskhakaia, M. Gachechiladze, J. Metreveli and M. Matchavariani \\ R. Agladze Institute of Inorganic Chemistry and Electrochemistry, Ivane Javakhishvili Tbilisi \\ State University, Tbilisi, Georgia
}

\begin{abstract}
The sorption of $\mathrm{Pb}$ (II) ions from an aqueous solution of lead nitrate on carbon sorbents, obtained from waste based on cellulose-containing materials, was studied. Particularly, among studied carbons (hazel nutshell, walnut shell, sawdust, activated carbon (fraction size - mainly 40 microns) material obtained from walnut shell shows the best adsorptive properties. The possibility of their use for the purification of drinking and waste waters contaminated with lead ions is established.
\end{abstract}

Keywords: Sorption, lead, adsorption, nutshell, carbon.

\section{INTRODUCTION}

Control of heavy metals content in natural waters is very important, because they are especially dangerous for human health. It must be mentioned, that metals often form water 
soluble complexes during chemical transformations in the medium. This complicates their removal by such well-known methods as coagulation, flotation, filtration, biochemical purification. However, the sorption method of water purification from heavy metals is the most effective way for neutralization of industrial wastewaters and for returning of pure water and precious metals to industry.

A problem of purification of drinking and waste waters is connected with their composition. In spite of the existence of general theoretical works in each particular instance it is necessary to select specific sorbent [1-15]. Therefore, creation of new cheap and effective adsorbents, especially on the basis of waste, is very important. Various sorbents were obtained from cellulose-contained waste by the help of worked out original technology $[13,14]$.

Lead is one of the most dangerous, environmentally toxic elements. Its accumulation in the environment is connected with the use of tetraethyl lead as an antidetonator, which is added to automotive fuel. Water contamination with lead is much higher in industrial regions. Lead accumulates in water in the form of ions or water-soluble complexes [1]. Removal of lead is realized by various methods, but the sorption method of water purification from lead is rather simple and effective method, which allows the neutralization of drinking and industrial wastewaters.

Maximum permissible concentration of lead ions in wastewaters is $1.0 \mathrm{mg} / \mathrm{L}$, and in drinking water is $0.01 \mathrm{mg} / \mathrm{L}$.

Search of new adsorbents in order to solve above mentioned problem in the world is very important. The analysis of literary data [2-15] has shown, that adsorbents, which were used for purification of drinking and wastewaters, oil products and organic solvents are characterized with high cost price and complicated regeneration technologies.

To compare the sorption capabilities of the materials obtained, the article presents some results for iron.

\section{MATERIALS AND METHODS}

This work is devoted to the adsorption of lead from aqueous medium by new carbon materials - adsorbents obtained from wastes based on cellulose-containing materials, according to the technology developed by the authors of this article [13, 14]. 
The advantage of worked out technology is that during thermochemical conversion, cheap reagent is added to the raw materials, which ensures the low price of the obtained carbonaceous material with high surface porosity. The possibility of use of obtained sorbents for the purification of drinking and waste water from lead ions is determined in this work.

Determination of the sorption activity of adsorbents with respect to lead ions $(\mathrm{A}, \mathrm{mg} / \mathrm{g})$ was carried out at a temperature $25^{\circ}-27^{\circ} \mathrm{C}$. A portion of the adsorbent $(1.0 \mathrm{~g})$ was stirred for 2 hours with $100 \mathrm{ml}$ of $0.01 \mathrm{M}$ lead nitrate solution $\mathrm{Pb}\left(\mathrm{NO}_{3}\right)_{2}$, after which the solution was separated from the sorbent by filtration and the concentration of metal ions was detected in it $\left(\mathrm{C}, \mathrm{C}_{0}, \mathrm{mg} / \mathrm{L}\right),\left(\mathrm{C}, \mathrm{C}_{0}\right.$ - was determined on atomic- absorptive spectrometer - AANALYST 200-1004 TAM AAS-200 - Perkin Elmer.

\section{Description of the process of obtaining carbonaceous material from walnut shells}

\section{(obtained at temperature $\mathrm{t}=750^{\circ} \mathrm{C}$ )}

Sample: walnut shells carbonaceous material (walnut shells from Sioni and Akhaltsikhe, Georgia). Materials are processed in a specially designed installation, in which a thermal process takes place with the addition of water according to a specific schedule.

For example, we give one of the time profiles of the process passing.

Initial weight of material for treatment $-4 \mathrm{~kg}$

Residual weight $-1.3 \mathrm{~kg}$

Starting: 9:45 min - The introduction of nitrogen at a temperature of $\mathrm{t}=0^{\circ} \mathrm{C}$ for 10 minutes

9:50 min - at $\mathrm{t}=260^{\circ} \mathrm{C}$ no gas evolution occurs.

9:55 min - at $\mathrm{t}=380^{\circ} \mathrm{C}$ no gas evolution occurs.

9:57 $\mathrm{min}$ - at $\mathrm{t}=398^{\circ} \mathrm{C}$ gas evolution begins.

10:04 $\mathrm{min}-$ at $\mathrm{t}=470^{\circ} \mathrm{C}$ gas evolution, burns with a yellow flame.

10:09 $\mathrm{min}-$ at $\mathrm{t}=500^{\circ} \mathrm{C}$ the beginning of distilled water supply (the rate of water supply does not change during the whole process).

10:15 $\mathrm{min}$ - at $\mathrm{t}=550^{\circ} \mathrm{C}$ intensive evolution of gas and water supply.

10:30min - at $\mathrm{t}=619^{\circ} \mathrm{C}$ intensive gas evolution and water supply. 
10:40 $\min -$ at $\mathrm{t}=651^{\circ} \mathrm{C}$ intensive evolution of gas and water supply.

11:00 $\min -$ at $\mathrm{t}=697^{\circ} \mathrm{C}$ intensive evolution of gas and water supply.

11:25 $\min -$ at $\mathrm{t}=737^{\circ} \mathrm{C}$ gas evolution decreases, water supply continues.

11:35 $\min -$ at $\mathrm{t}=750^{\circ} \mathrm{C}$ gas evolution stops and water supply continues.

Within 2 hours the sample was kept at $\mathrm{t}=750^{\circ} \mathrm{C}$. In total, 2 liters of water were consumed.

3 liters of oily liquid was poured from the refrigerator on the gas evolution line.

\section{Adsorption of lead ions on carbonaceous material of walnut shells (obtained at $t=750^{\circ} \mathrm{C}$ )}

For the experiment $1 \mathrm{~g}$ of walnut shells carbonaceous material of fraction 40 and 50 micron was taken, added to $0.01 \mathrm{M}$ solution of lead nitrate $\mathrm{Pb}\left(\mathrm{NO}_{3}\right)_{2}$ and stirred on a magnetic stirrer during different times 5, 10, 20, 30, 60, 90 and 120 minutes. Solutions were filtered and concentration of filtrate was measured on an atomic-absorption spectrometer AANALYST 200-1004 TAM AAS-200 - Perkin Elmer.

The results are given in Tables 1 and 2 .

Table 1. Concentrations (initial $\mathrm{C}_{0}$ and final $\mathrm{C}$ ) and adsorption values $(\mathrm{A}, \mathrm{mg} / \mathrm{g})$ of lead ions $\left(\mathrm{Pb}^{++}\right)$after different delay times (with stirring) in solution of the adsorbent obtained from carbonaceous material of walnut shells (fraction size 50 micron), $\left(\mathrm{m}_{\text {sorb. }}=1 \mathrm{~g}, \mathrm{~V}_{\text {sol. }}=100 \mathrm{ml}, \mathrm{C}_{0}=2.09 \mathrm{~g} / \mathrm{L}, \mathrm{t}=25-27^{0} \mathrm{C}\right.$ ).

\begin{tabular}{|c|c|c|c|c|}
\hline Time, min & $\begin{array}{l}\text { Initial } \\
\text { concentration, } \mathrm{C}_{0} \text {, } \\
\mathrm{g} / \mathrm{L}\end{array}$ & $\begin{array}{l}\text { Final } \\
\text { concentration, } \mathrm{C} \text {, } \\
\mathrm{g} / \mathrm{L}\end{array}$ & $\mathrm{A}, \mathrm{mg} / \mathrm{g}$ & $\begin{array}{l}\text { Purification rate, } \\
\%\end{array}$ \\
\hline 5 & \multirow{7}{*}{2.09} & 1.23 & 86 & 41.15 \\
\hline 10 & & 1.25 & 84 & 40.19 \\
\hline 20 & & 1.24 & 85 & 40.66 \\
\hline 30 & & 1.28 & 81 & 38.76 \\
\hline 60 & & 1.23 & 86 & 41.15 \\
\hline 90 & & 1.25 & 84 & 40.19 \\
\hline 120 & & 1.37 & 72 & 34.45 \\
\hline
\end{tabular}


Table 2. Concentrations (initial $\mathrm{C}_{0}$ and final $\mathrm{C}$ ) and adsorption values $(\mathrm{A}, \mathrm{mg} / \mathrm{g})$ of lead ions $\left(\mathrm{Pb}^{++}\right)$after different delay times (with stirring) in solution of the adsorbent obtained from carbonaceous material of walnut shells (fraction size 40 micron), $\left(\mathrm{m}_{\text {sorb. }}=1 \mathrm{~g}, \mathrm{~V}_{\text {sol. }}=100 \mathrm{ml}, \mathrm{C}_{0 .}=2.09 \mathrm{~g} / \mathrm{L}, \mathrm{t}=25-27^{\circ} \mathrm{C}\right.$ ).

\begin{tabular}{|c|c|c|c|c|}
\hline Time, $\min$ & $\begin{array}{l}\text { Initial concentration, } \\
\mathrm{C}_{0}, \mathrm{~g} / \mathrm{L}\end{array}$ & $\begin{array}{l}\text { Final } \\
\text { concentration, } \mathrm{C}, \\
\mathrm{g} / \mathrm{L}\end{array}$ & $\mathrm{A}, \mathrm{mg} / \mathrm{g}$ & $\begin{array}{l}\text { Purification rate, } \\
\%\end{array}$ \\
\hline 5 & & 1.32 & 77 & 36.84 \\
\hline 10 & \multirow{6}{*}{2.09} & 1.29 & 80 & 38.28 \\
\hline 20 & & 1.22 & 87 & 41.63 \\
\hline 30 & & 1.27 & 82 & 38.27 \\
\hline 60 & & 1.20 & 89 & 42.58 \\
\hline 90 & & 1.21 & 88 & 42.11 \\
\hline 120 & & 1.23 & 86 & 41.15 \\
\hline
\end{tabular}

Conclusion: Equilibrium concentration was established within 1-1.5 hours.

\section{Effect of pH on the adsorption of lead ions on the carbonaceous material of walnut shells (obtained at $\mathrm{t}=\mathbf{7 5 0}^{\circ} \mathrm{C}$ )}

For the experiment $1 \mathrm{~g}$ of walnut shell carbonaceous material of fraction 40 micron was taken, added in $100 \mathrm{ml}$ of lead nitrate solutions $\left(\mathrm{Pb}\left(\mathrm{NO}_{3}\right)_{2}\right)$, with different $\mathrm{pH}-2,3,4$ and 5 . The solutions were stirred on a magnetic stirrer during 90 minutes. Experiment was carried out at room temperature $\left(\mathrm{t}=25-27 \mathrm{C}^{0}\right)$. The samples were filtered and the concentration of residuary lead ions in the filtrate was determined with the help of an atomic-absorption spectrometer AANALYST 200-1004 TAM AAS-200 - Perkin Elmer.

The results are given in Table 3. 
Table 3. Adsorption of lead ions at different $\mathrm{pH}$ on adsorbent obtained from carbonaceous material of walnut shells (fraction size 40 micron), concentrations (initial $\mathrm{C}_{0}$ and final $\mathrm{C}$ ) and adsorption values (A, $\mathrm{mg} / \mathrm{g})$ of lead ions $\left(\mathrm{Pb}^{++}\right)\left(\mathrm{m}_{\text {sorb. }}=1 \mathrm{~g}, \mathrm{~V}_{\text {sol. }}=100 \mathrm{ml}, \mathrm{t}=90 \mathrm{~min}, \mathrm{t}=25-27^{0} \mathrm{C}\right)$.

\begin{tabular}{|l|l|l|l|l|}
\hline $\mathrm{pH}$ & $\begin{array}{l}\text { Initial } \\
\text { concentration, } \mathrm{C}, \mathrm{f}, \mathrm{g} / \mathrm{L} \\
\mathrm{g} / \mathrm{L}\end{array}$ & $\begin{array}{l}\text { Final concentration } \\
\mathrm{A}, \mathrm{mg} / \mathrm{g}\end{array}$ & $\begin{array}{l}\text { Purification rate, } \\
\%\end{array}$ \\
\hline 2 & 1.95 & 1.76 & 19 & 9.59 \\
\hline 3 & 1.88 & 1.21 & 65 & 34.57 \\
\hline 4 & 2.0 & 1.19 & 79 & 39.50 \\
\hline 5 & 2.05 & 86 & 46.83 \\
\hline
\end{tabular}

Conclusion: The adsorbent obtained from walnut shells shows good adsorption capacity when $\mathrm{pH}=5$.

Effect of temperature on the adsorption of lead ions on the carbonaceous material of walnut shells (obtained at $750^{\circ} \mathrm{C}$ )

For the experiment $1 \mathrm{~g}$ of walnut shells carbonaceous material of fraction 40 micron was taken and $100 \mathrm{ml}$ of lead nitrate $0.01 \mathrm{M}$ solution was added. The samples were stirred on a magnetic stirrer at different temperatures, particularly at 25, 40, 50, 60 and $70{ }^{\circ} \mathrm{C}$ during 90 minutes. The samples were filtered, and the concentration of lead remaining in the filtrate was measured with an atomic-absorption spectrometer AANALYST 200-1004 TAM AAS200 - Perkin Elmer.

Table 4. Adsorption of lead ions on adsorbent obtained from walnut shells (fraction size 40 micron) at different temperatures, concentrations (initial $\mathrm{C}_{0}$ and final $\mathrm{C}$ ) and adsorption values $(\mathrm{A}, \mathrm{mg} / \mathrm{g})$ of lead ions $\left(\mathrm{Pb}^{++}\right)\left(\mathrm{m}_{\text {sorb. }}=1 \mathrm{~g}, \mathrm{~V}_{\text {sol. }}=100 \mathrm{ml}, \tau=90 \mathrm{~min}\right)$

\begin{tabular}{|l|l|l|l|l|}
\hline $\begin{array}{l}\text { Temperature, } \\
{ }^{0} \mathrm{C}\end{array}$ & $\begin{array}{l}\text { Initial concentration, } \\
\mathrm{C}_{0}, \mathrm{~g} / \mathrm{L}\end{array}$ & $\begin{array}{l}\text { Final concentration, } \\
\mathrm{C}, \mathrm{g} / \mathrm{L}\end{array}$ & $\mathrm{A}, \mathrm{mg} / \mathrm{g}$ & $\begin{array}{l}\text { Purification } \\
\text { rate, } \%\end{array}$ \\
\hline 25 & 2.02 & 1.14 & 88 & 49.50 \\
\hline 40 & 2.02 & 1.29 & 73 & 36.14 \\
\hline
\end{tabular}




\begin{tabular}{|l|l|l|l|l|}
\hline 50 & 2.02 & 1.21 & 81 & 40.09 \\
\hline 60 & 2.02 & 1.27 & 75 & 37.12 \\
\hline 90 & 2.02 & 1.29 & 73 & 36.14 \\
\hline
\end{tabular}

Conclusion: the best adsorption is achieved at $25 \mathrm{C}^{0}$.

Description of the process of obtaining carbonaceous material from walnut shells (obtained at $\mathrm{t}=650^{\circ} \mathrm{C}$ )

Sample: walnut shells carbonaceous material (walnut shells from Sioni and Akhaltsikhe, Georgia).

Initial weight $-1 \mathrm{~kg}$.

Residual weight -220 g.

Starting: 9h $20 \mathrm{~min}$.

Evolution of smoke $\mathrm{t}=380^{\circ} \mathrm{C}$.

Water supply $13: 27 \min \mathrm{t}=500^{\circ} \mathrm{C}$.

Intensive evolution 13:27 $\min \mathrm{t}=500^{\circ} \mathrm{C}$ burns with yellow flame.

$13: 33 \min \mathrm{t}=650^{\circ} \mathrm{C}$.

Intensity decreases $13: 38 \min \mathrm{t}=650^{\circ} \mathrm{C}$.

Description of the process of obtaining carbonaceous material from hazelnut shells (obtained at $\mathrm{t}=850^{\circ} \mathrm{C}$ )

Sample: hazelnut shells.

The measurements were carried out in another reactor (small size).

Initial weight - $1400 \mathrm{~g}$.

Starting $13: 50 \min \mathrm{t}=70^{\circ} \mathrm{C}$.

$13: 53 \mathrm{~min}-\mathrm{t}=300^{\circ} \mathrm{C}$ water supply.

13:57 min - at $\mathrm{t}=480^{\circ} \mathrm{C}$ gas evolution begins. 
14:00 $\min -$ at $\mathrm{t}=550^{\circ} \mathrm{C}$ intensive gas evolution begins.

14:10 $\min -\mathrm{t}=720^{\circ} \mathrm{C}$ intensive gas evolution.

14:20 $\min -\mathrm{t}=850^{\circ} \mathrm{C}$ intensive gas evolution.

Intensive gas evolution at $\mathrm{t}=850^{\circ} \mathrm{C}$ was observed until 16:20 min.

Shutdown 16:20 min.

Heating for $30 \mathrm{~min}$ ( $8500 \mathrm{C}-2$ hours), supply of $1.400 \mathrm{~L}$ of water.

Argon purging to displace air (oxygen) from the reactor 13:40 - 13:50 min (10 minutes).

\section{Adsorption of lead ions on different carbonaceous material: walnut shell (obtained at} $650^{\circ} \mathrm{C}$ ), hazelnut shell (obtained at $850^{\circ} \mathrm{C}$ in small size reactor), factory-made activated carbon.

Parallel experiments were carried out on carbonaceous materials obtained from walnut shells and hazelnut shells. For comparison was used factory-made activated carbon. The results are given Tables 5, 6, and 7 .

Table 5. Concentrations (initial $\mathrm{C}_{0}$ and final $\mathrm{C}$ ) and adsorption values $(\mathrm{A}, \mathrm{mg} / \mathrm{g})$ of lead ions $\left(\mathrm{Pb}^{++}\right)$after different delay times (with stirring) in lead nitrate solution of the adsorbent obtained from carbonaceous material of walnut shells (fraction size 50 micron), $\left(\mathrm{m}_{\text {sorb. }}=1 \mathrm{~g}, \mathrm{~V}_{\text {sol. }}=100 \mathrm{ml}, \mathrm{C}_{0}=2.1 \mathrm{~g} / \mathrm{L}, \mathrm{t}=25-27^{0} \mathrm{C}\right.$ ).

\begin{tabular}{|c|c|c|c|c|}
\hline Time, min & $\begin{array}{l}\text { Initial } \\
\text { concentration, } \mathrm{C}_{0} \text {, } \\
\mathrm{g} / \mathrm{L}\end{array}$ & $\begin{array}{l}\text { Final } \\
\text { concentration, } \mathrm{C} \text {, } \\
\mathrm{g} / \mathrm{L}\end{array}$ & $\mathrm{A}, \mathrm{mg} / \mathrm{g}$ & $\begin{array}{l}\text { Purification rate, } \\
\%\end{array}$ \\
\hline 5 & \multirow{7}{*}{2.1} & 1.7 & 40 & 19.05 \\
\hline 10 & & 1.89 & 21 & 10.00 \\
\hline 20 & & 1.81 & 29 & 13.81 \\
\hline 30 & & 1.71 & 39 & 18.57 \\
\hline 60 & & 1.82 & 28 & 13.33 \\
\hline 90 & & 1.76 & 34 & 16.19 \\
\hline 120 & & 1.75 & 35 & 16.67 \\
\hline
\end{tabular}


Table 6. Concentrations (initial $\mathrm{C}_{0}$ and final $\mathrm{C}$ ) and adsorption values $(\mathrm{A}, \mathrm{mg} / \mathrm{g})$ of lead ions $\left(\mathrm{Pb}^{++}\right)$after different delay times (with stirring) in lead nitrate solution of the adsorbent obtained from carbonaceous material of hazelnut shells (fraction size 50 micron, reactor), $\left(\mathrm{m}_{\text {sorb. }}=1 \mathrm{~g}, \mathrm{~V}_{\text {sol. }}=100 \mathrm{ml}, \mathrm{C}_{0}=2.1 \mathrm{~g} / \mathrm{L}, \mathrm{t}=25\right.$ $\left.27^{0} \mathrm{C}\right)$.

\begin{tabular}{|c|c|c|c|c|}
\hline Time, $\min$ & $\begin{array}{l}\text { Initial } \\
\text { concentration, } \mathrm{C}_{0}, \\
\mathrm{~g} / \mathrm{L}\end{array}$ & $\begin{array}{l}\text { Final } \\
\text { concentration, } C, \\
\text { g/L }\end{array}$ & $\mathrm{A}, \mathrm{mg} / \mathrm{g}$ & $\begin{array}{l}\text { Purification rate, } \\
\%\end{array}$ \\
\hline 5 & \multirow{7}{*}{2.1} & 1.44 & 66 & 31.43 \\
\hline 10 & & 1.40 & 70 & 33.33 \\
\hline 20 & & 1.36 & 74 & 35.24 \\
\hline 30 & & 1.37 & 73 & 34.76 \\
\hline 60 & & 1.30 & 80 & 38.10 \\
\hline 90 & & 1.27 & 83 & 39.52 \\
\hline 120 & & 1.23 & 87 & 41.43 \\
\hline
\end{tabular}

Table 7. Concentrations (initial $\mathrm{C}_{0}$ and final $\mathrm{C}$ ) and adsorption values $(\mathrm{A}, \mathrm{mg} / \mathrm{g})$ of lead ions $\left(\mathrm{Pb}^{++}\right)$after different delay times (with stirring) in lead nitrate solution of the factory-made activated carbon (fraction size 50 micron), $\left(\mathrm{m}_{\text {sorb. }}=1 \mathrm{~g}, \mathrm{~V}_{\text {sol. }}=100 \mathrm{ml}, \mathrm{C}_{0}=2.1 \mathrm{~g} / \mathrm{L}, \mathrm{t}=25-27^{\circ} \mathrm{C}\right)$.

\begin{tabular}{|c|c|c|c|c|}
\hline Time, min & $\begin{array}{l}\text { Initial } \\
\text { concentration, } \mathrm{C}_{0}, \\
\mathrm{~g} / \mathrm{L}\end{array}$ & $\begin{array}{l}\text { Final } \\
\text { concentration, } \quad \mathrm{C}, \\
\mathrm{g} / \mathrm{L}\end{array}$ & $\mathrm{A}, \mathrm{mg} / \mathrm{g}$ & $\begin{array}{l}\text { Purification rate, } \\
\%\end{array}$ \\
\hline 5 & \multirow{7}{*}{2.1} & 1.39 & 71 & 33.81 \\
\hline 10 & & 1.36 & 74 & 35.24 \\
\hline 20 & & 1.24 & 86 & 40.95 \\
\hline 30 & & 1.32 & 78 & 37.14 \\
\hline 60 & & 1.33 & 77 & 36.67 \\
\hline 90 & & 1.33 & 77 & 36.67 \\
\hline 120 & & 1.25 & 85 & 40.48 \\
\hline
\end{tabular}

In addition, parallel experiments were carried out with factory-made activated carbon and adsorbents obtained from walnut shells. The results are shown in Tables 8, 9. 
Table 8. Concentrations (initial $\mathrm{C}_{0}$ and final $\mathrm{C}$ ) and adsorption values $(\mathrm{A}, \mathrm{mg} / \mathrm{g})$ of lead ions $\left(\mathrm{Pb}^{++}\right)$after different delay times (with stirring) in lead nitrate solution of the factory-made activated carbon (fraction size 50micron), $\left(\mathrm{m}_{\text {sorb. }}=1 \mathrm{~g}, \mathrm{~V}_{\text {sol. }}=100 \mathrm{ml}, \mathrm{C}_{0}=2.1 \mathrm{~g} / \mathrm{L}, \mathrm{t}=25-27^{\circ} \mathrm{C}\right)$.

\begin{tabular}{|c|c|c|c|c|}
\hline Time, min & $\begin{array}{l}\text { Initial } \\
\text { concentration, } \mathrm{C}_{0} \text {, } \\
\mathrm{g} / \mathrm{L}\end{array}$ & $\begin{array}{l}\text { Final } \\
\text { concentration, C, } \\
\mathrm{g} / \mathrm{L}\end{array}$ & $\mathrm{A}, \mathrm{mg} / \mathrm{g}$ & $\begin{array}{l}\text { Purification rate, } \\
\%\end{array}$ \\
\hline 5 & \multirow{7}{*}{2.1} & 1.33 & 77 & 36.67 \\
\hline 10 & & 1.30 & 80 & 38.10 \\
\hline 20 & & 1.17 & 93 & 44.29 \\
\hline 30 & & 1.26 & 84 & 40.00 \\
\hline 60 & & 1.23 & 87 & 41.43 \\
\hline 90 & & 1.17 & 93 & 44.29 \\
\hline 120 & & 1.15 & 95 & 45.24 \\
\hline
\end{tabular}

Table 9. Concentrations (initial $\mathrm{C}_{0}$ and final $\mathrm{C}$ ) and adsorption values $(\mathrm{A}, \mathrm{mg} / \mathrm{g})$ of lead ions $\left(\mathrm{Pb}^{++}\right)$after different delay times (with stirring) in lead nitrate solution of the adsorbent obtained from carbonaceous material of walnut shells (fraction size 50 micron), $\left(\mathrm{m}_{\text {sorb. }}=1 \mathrm{~g}, \mathrm{~V}_{\text {sol. }}=100 \mathrm{ml}, \mathrm{C}_{0}=2.2 \mathrm{~g} / \mathrm{L}, \mathrm{t}=25-27^{\circ} \mathrm{C}\right.$ ).

\begin{tabular}{|c|c|c|c|c|}
\hline Time, min & $\begin{array}{l}\text { Initial } \\
\text { concentration, } \mathrm{C}_{0}, \\
\mathrm{~g} / \mathrm{L}\end{array}$ & $\begin{array}{l}\text { Final } \\
\text { concentration, C, } \\
\mathrm{g} / \mathrm{L}\end{array}$ & $\mathrm{A}, \mathrm{mg} / \mathrm{g}$ & $\begin{array}{l}\text { Purification rate, } \\
\%\end{array}$ \\
\hline 5 & \multirow{7}{*}{2.2} & 1.71 & 49 & 22.27 \\
\hline 10 & & 1.66 & 54 & 24.55 \\
\hline 20 & & 1.47 & 73 & 33.18 \\
\hline 30 & & 1.82 & 38 & 17.27 \\
\hline 60 & & 1.73 & 47 & 21.36 \\
\hline 90 & & 1.73 & 47 & 21.36 \\
\hline 120 & & 1.68 & 52 & 23.64 \\
\hline
\end{tabular}

Adsorption of lead ions on various amounts of walnut shells carbonaceous material (obtained at $750^{\circ} \mathrm{C}$ ) 
For the experiment was taken various amounts, particularly, 2, 3, 4 and $5 \mathrm{~g}$ of walnut shells carbonaceous material. Each amount was added to a $0.01 \mathrm{M}$ solution of lead nitrate $\mathrm{Pb}\left(\mathrm{NO}_{3}\right)_{2}$ and stirred on a magnetic stirrer during 5 minutes. The solutions were filtered and the concentration of residual lead ions in the filtrate was measured using an atomic-absorption spectrometer AANALYST 200-1004 TAM AAS-200 - Perkin Elmer.

The results are shown in Table 10.

Table 10. Concentrations (initial $\mathrm{C}_{0}$ and final $\mathrm{C}$ ) and adsorption values $(\mathrm{A}, \mathrm{mg} / \mathrm{g})$ of lead ions $\left(\mathrm{Pb}^{++}\right)$after delay (with stirring) in solution of the different amounts of adsorbent obtained from carbonaceous material of walnut shells (fraction size 40 micron), ( $\mathrm{m}_{\text {sorb. }}=1,2,3,4,5 \mathrm{~g}$., $\mathrm{V}_{\text {sol. }}=100 \mathrm{ml}, \mathrm{C}_{0}=1.95 \mathrm{~g} / \mathrm{L}, \mathrm{t}=25-27^{\circ} \mathrm{C}$ ).

\begin{tabular}{|l|l|l|l|l|l|}
\hline $\begin{array}{l}\text { Time, } \\
\text { min }\end{array}$ & $\begin{array}{l}\text { Concentration of } \\
\text { initial solution, } \\
\mathrm{C}_{0}, \mathrm{~g} / \mathrm{L}\end{array}$ & $\begin{array}{l}\text { Quantity } \\
\text { carbonaceous } \\
\text { material, } \mathrm{g}\end{array}$ & $\begin{array}{l}\text { of } \\
\text { concentration, C, } \\
\mathrm{g} / \mathrm{L}\end{array}$ & $\mathrm{A} \mathrm{mg/g}$ & $\begin{array}{l}\text { Purification } \\
\text { rate, \% }\end{array}$ \\
\hline \multirow{2}{*}{5} & 1.95 & 1.30 & 65 & 33 \\
\cline { 3 - 6 } & 2 & 0.67 & 64 & 66 \\
\cline { 3 - 6 } & 3 & 0.39 & 52 & 80 \\
\hline & 4 & 0.11 & 46 & 94 \\
\hline
\end{tabular}

Conclusion: About $96 \%$ of lead ions can be removed from every $100 \mathrm{ml}$ of $0.01 \mathrm{M}$ solution in 5 minutes using $5 \mathrm{~g}$ of adsorbent.

\section{Adsorption of lead ions on lead solutions of different concentrations}

For the experiment was taken $1 \mathrm{~g}$ of walnut shells carbonaceous material and added to 0.005 $\mathrm{M}, 0.01 \mathrm{M}$ and $0.02 \mathrm{M}$ solution of lead nitrate $\mathrm{Pb}\left(\mathrm{NO}_{3}\right)_{2}$ and stirred on a magnetic stirrer for 1.3 and 5 minutes. The solutions were filtered and the concentration of residual lead ions in the filtrate was measured using an atomic-absorption spectrometer AANALYST 200-1004 TAM AAS-200 - Perkin Elmer.

The results are shown in Tables 11, 12, and 13. 
Table 11. Concentrations (initial $\mathrm{C}_{0}$ and final $\mathrm{C}$ ) and adsorption values $(\mathrm{A}, \mathrm{mg} / \mathrm{g})$ of lead ions $\left(\mathrm{Pb}^{++}\right)$after delay (with stirring) in solution of adsorbent obtained from carbonaceous material of walnut shells (fraction size 40 micron), $\left(\mathrm{m}_{\text {sorb. }}=1 \mathrm{~g}, \mathrm{~V}_{\text {sol. }}=100 \mathrm{ml}, \mathrm{C}_{0 .}=3.6 \mathrm{~g} / \mathrm{L}, \mathrm{t}=25-27^{\circ} \mathrm{C}\right.$ ).

\begin{tabular}{|c|c|c|c|c|c|}
\hline $\begin{array}{l}\text { Molarity of } \\
\text { solution }\end{array}$ & $\begin{array}{l}\text { Time, } \\
\text { min }\end{array}$ & $\begin{array}{l}\text { Initial } \\
\text { concentration, } \\
\mathrm{C}_{0}, \mathrm{~g} / \mathrm{L}\end{array}$ & $\begin{array}{l}\text { Final concentration, } \\
\mathrm{C}, \mathrm{g} / \mathrm{L}\end{array}$ & $\mathrm{A}, \mathrm{mg} / \mathrm{g}$ & $\begin{array}{l}\text { Purification } \\
\text { rate, } \%\end{array}$ \\
\hline \multirow{3}{*}{0.02} & 1 & \multirow[t]{3}{*}{3.6} & 2.80 & 80 & 22 \\
\hline & 3 & & 2.97 & 63 & 18 \\
\hline & 5 & & 2.99 & 61 & 17 \\
\hline
\end{tabular}

Table 12. Concentrations (initial $\mathrm{C}_{0}$ and final $\left.\mathrm{C}\right)$ and adsorption values $(\mathrm{A}, \mathrm{mg} / \mathrm{g})$ of lead ions $\left(\mathrm{Pb}^{++}\right)$after delay (with stirring) in solution of adsorbent obtained from carbonaceous material of walnut shells (fraction size 40 micron), $\left(\mathrm{m}_{\text {sorb. }}=1 \mathrm{~g}, \mathrm{~V}_{\text {sol. }}=100 \mathrm{ml}, \mathrm{C}_{0 .}=1.99 \mathrm{~g} / \mathrm{L}, \mathrm{t}=25-27^{\circ} \mathrm{C}\right.$ ).

\begin{tabular}{|c|c|c|c|c|c|}
\hline $\begin{array}{l}\text { Molarity of } \\
\text { solution }\end{array}$ & $\begin{array}{l}\text { Time, } \\
\min \end{array}$ & $\begin{array}{l}\text { Initial } \\
\text { concentration, } \mathrm{C}_{0} \text {, } \\
\mathrm{g} / \mathrm{L}\end{array}$ & $\begin{array}{l}\text { Final concentration, } C \\
g / L\end{array}$ & $\mathrm{~A}, \mathrm{mg} / \mathrm{g}$ & $\begin{array}{l}\text { Purification } \\
\text { rate, } \%\end{array}$ \\
\hline \multirow{3}{*}{0.01} & 1 & \multirow[t]{3}{*}{1.99} & 1.34 & 65 & 33 \\
\hline & 3 & & 1.35 & 64 & 32 \\
\hline & 5 & & 1.28 & 71 & 36 \\
\hline
\end{tabular}

The filtrate of the sample, which was stirred for $5 \mathrm{~min}$, was treated twice with an adsorbent obtained from walnut shells; the amount of adsorbent corresponded to the volume of the filtrate. Lead ions were completely recovered from the filtrate, which was treated twice.

Table 13. Concentrations (initial $\mathrm{C}_{0}$ and final $\mathrm{C}$ ) and adsorption values $(\mathrm{A}, \mathrm{mg} / \mathrm{g})$ of lead ions $\left(\mathrm{Pb}^{++}\right)$after delay (with stirring) in solution of adsorbent obtained from carbonaceous material of walnut shells (fraction size 40 micron), $\left(\mathrm{m}_{\text {sorb. }}=1 \mathrm{~g}, \mathrm{~V}_{\text {sol. }}=100 \mathrm{ml}, \mathrm{C}_{0 .}=0.98 \mathrm{~g} / \mathrm{L}, \mathrm{t}=25-27^{0} \mathrm{C}\right.$ ).

\begin{tabular}{|l|l|l|l|l|l|}
\hline $\begin{array}{l}\text { Molarity of } \\
\text { solution }\end{array}$ & $\begin{array}{l}\text { Time, } \\
\min \end{array}$ & $\begin{array}{l}\text { Initial } \\
\text { concentration, } \mathrm{C}_{0}, \\
\mathrm{~g} / \mathrm{L}\end{array}$ & $\begin{array}{l}\text { Final concentration, } \\
\mathrm{C}, \mathrm{g} / \mathrm{L}\end{array}$ & A, mg/g & $\begin{array}{l}\text { Purification } \\
\text { rate, \% }\end{array}$ \\
\hline \multirow{2}{*}{0.005} & 0.98 & 0.49 & 49 & 50 \\
\cline { 4 - 6 } & \multirow{2}{*}{3} & & 0.49 & 49 & 50 \\
\hline
\end{tabular}




\begin{tabular}{|l|l|l|l|l|l|}
\hline & 5 & & 0.40 & 58 & 59 \\
\hline
\end{tabular}

\section{Conclusions:}

a) The higher the concentration of the solution, the less time it takes to achieve high adsorption (although of a comparatively lower quality than in dilute solutions).

b) In dilute solutions $(0.98 \mathrm{~g} / \mathrm{L}), 1 \mathrm{~g}$ of adsorbent can reduce the lead concentration by half from $100 \mathrm{ml}$ of solution.

\section{Adsorption of lead ions on different amounts of various carbonaceous material (hazelnut shell obtained at $850^{\circ} \mathrm{C}$, in small size reactor).}

For the experiment was taken various amounts, particularly, 2, 3 and $4 \mathrm{~g}$ of hazelnut shells carbonaceous material. Each amount was added to $100 \mathrm{ml} 0.01 \mathrm{M}$ solution of lead nitrate $\mathrm{Pb}\left(\mathrm{NO}_{3}\right)_{2}$ and stirred on a magnetic stirrer during 5 minutes. After stirring the solutions were filtered and the concentration of residual lead ions in the filtrate was measured using an atomic-adsorption spectrometer AANALYST 200-1004 TAM AAS-200 - Perkin Elmer.

The results are shown in Table 14.

Table 14. Concentrations (initial $\mathrm{C}_{0}$ and final $\mathrm{C}$ ) and adsorption values $(\mathrm{A}, \mathrm{mg} / \mathrm{g})$ of lead ions $\left(\mathrm{Pb}^{++}\right) \mathrm{after}$ delay (with stirring) in solution of the different amounts of adsorbent obtained from carbonaceous material of hazelnut shells (fraction size 40 micron), $\left(\mathrm{m}_{\text {sorb. }}=2,3,4 \mathrm{~g}, \mathrm{~V}_{\text {sol. }}=100 \mathrm{ml}, \mathrm{C}_{0 .}=2.1 \mathrm{~g} / \mathrm{L}, \tau=5 \mathrm{~min}, \mathrm{t}=25\right.$ $\left.27^{0} \mathrm{C}\right)$.

\begin{tabular}{|l|l|l|l|l|l|l|}
\hline Sample & $\begin{array}{l}\text { Time, } \\
\min \end{array}$ & $\mathrm{C}_{0}, \mathrm{~g} / \mathrm{L}$ & $\mathrm{m}_{\text {sorb }}, \mathrm{g}$ & $\mathrm{C}, \mathrm{g} / \mathrm{L}$ & $\mathrm{A}, \mathrm{m} \mathrm{g} / \mathrm{g}$ & $\begin{array}{l}\text { Purification } \\
\text { rate, } \%\end{array}$ \\
\hline $\begin{array}{l}\text { Carbonaceous } \\
\text { material of hazelnut } \\
\text { shells }\end{array}$ & 5 & 2.1 & 3 & 0.56 & 77 & 73.3 \\
\cline { 3 - 7 } & & & 4 & 0.11 & 50 & 94.2 \\
\hline
\end{tabular}

Adsorption of ferric ions on different amounts of various carbonaceous material: hazelnut shell (obtained at $850^{\circ} \mathrm{C}$, in small size reactor), walnut shell (obtained at $750^{\circ} \mathrm{C}$ ), factory-made activated carbon. 
For the experiment was taken 2, 3, 4 and $5 \mathrm{~g}$ of various carbonaceous material - walnut shells, hazelnut shells and factory-made activated carbon and was added to $100 \mathrm{ml} 0.01 \mathrm{M}$ solution of ferric sulfate $\left(\mathrm{FeSO}_{4} \cdot 7 \mathrm{H}_{2} \mathrm{O}\right)$, and stirred on a magnetic stirrer during 90 minutes. The solutions were filtered and the concentration of residual ferric ions in the filtrate was measured using Zuzi spectrophotometer 4201/50.

Table 15. Concentrations (initial $\mathrm{C}_{0}$ and final $\mathrm{C}$ ) and adsorption values (A, $\mathrm{mg} / \mathrm{g}$ ) of $\mathrm{Fe}^{++}$ions after delay time (with stirring) in different amounts of solution of the adsorbent obtained from carbonaceous material of hazelnut shells (fraction size 40 micron), $\left(\mathrm{m}_{\text {sorb. }}=2,3,4 \mathrm{~g}\right.$,

$\left.\mathrm{V}_{\text {sol. }}=100 \mathrm{ml}, \mathrm{C}_{0}=0.59 \mathrm{~g} / \mathrm{L}, \tau=90 \mathrm{~min}, \mathrm{t}=25-27^{\circ} \mathrm{C}\right)$.

\begin{tabular}{|l|l|l|l|l|l|}
\hline Sample & $\begin{array}{l}\text { Initial } \\
\text { concentration, } \\
\text { Co, } / \mathrm{L}\end{array}$ & $\begin{array}{l}\text { Amount } \\
\text { sample, } \mathrm{g}\end{array}$ & $\begin{array}{l}\text { Final } \\
\text { concentration, C, } \\
\mathrm{g} / \mathrm{L}\end{array}$ & A, mg/g & $\begin{array}{l}\text { Purification } \\
\text { rate, \% }\end{array}$ \\
\hline $\begin{array}{l}\text { Carbonaceous } \\
\text { material of } \\
\text { hazelnut shells }\end{array}$ & 0.59 & 2 & 0.092 & 24.9 & 84.4 \\
\cline { 2 - 6 } & 3 & 0.00046 & 19.7 & 100 \\
\cline { 2 - 6 } & 4 & 0.00008 & 14.75 & 100 \\
\hline
\end{tabular}

Table 16. Concentrations (initial $\mathrm{C}_{0}$ and final $\mathrm{C}$ ) and adsorption values $(\mathrm{A}, \mathrm{mg} / \mathrm{g})$ of $\mathrm{Fe}^{++}$ions after delay time (with stirring) in different amounts of solution of the adsorbent obtained from carbonaceous material of walnut shells (fraction size 40 micron), ( $\mathrm{m}_{\text {sorb. }}=2,3,4 \mathrm{~g}, \mathrm{~V}_{\text {sol. }}=100 \mathrm{ml}, \mathrm{C}_{0}=0.59 \mathrm{~g} / \mathrm{L}, \tau=90 \mathrm{~min}, \mathrm{t}=25$ $\left.27^{0} \mathrm{C}\right)$.

\begin{tabular}{|c|c|c|c|c|c|}
\hline Sample & $\begin{array}{l}\text { Initial } \\
\text { concentration } \mathrm{C}_{0} \\
\mathrm{~g} / \mathrm{L}\end{array}$ & $\begin{array}{l}\text { Amount of } \\
\text { sample, } g\end{array}$ & $\begin{array}{l}\text { Final } \\
\text { concentration, C } \\
\mathrm{g} / \mathrm{L}\end{array}$ & $\mathrm{A} \mathrm{mg} / \mathrm{g}$ & $\begin{array}{l}\text { Purification } \\
\text { rate, } \%\end{array}$ \\
\hline \multirow{3}{*}{$\begin{array}{l}\text { Carbonaceous } \\
\text { material of } \\
\text { walnut shells }\end{array}$} & \multirow{3}{*}{0.59} & 2 & 0.22 & 18.5 & 62.7 \\
\hline & & 3 & 0.04 & 18.3 & 93.2 \\
\hline & & 4 & 0.00022 & 14.74 & 100 \\
\hline
\end{tabular}

Table 17. Concentrations (initial $\mathrm{C}_{0}$ and final $\mathrm{C}$ ) and adsorption values (A, $\mathrm{mg} / \mathrm{g}$ ) of $\mathrm{Fe}^{++}$ions after delay time (with stirring) in different amounts of solution of the adsorbent obtained from carbonaceous material of activated carbon (fraction size 40 micron), ( $\mathrm{m}_{\text {sorb. }}=2,3,4 \mathrm{~g}, \mathrm{~V}_{\text {sol. }}=100 \mathrm{ml}, \mathrm{C}_{0}=0.59 \mathrm{~g} / \mathrm{L}, \mathrm{t}=90 \mathrm{~min}, \mathrm{t}=$ $\left.25-27^{0} \mathrm{C}\right)$.

\begin{tabular}{|l|l|l|l|l|l|}
\hline Sample & Initial & Amount of & Final & & Purification \\
\hline
\end{tabular}




\begin{tabular}{|c|c|c|c|c|c|}
\hline & $\begin{array}{l}\text { concentration } \mathrm{C}_{0} \\
\mathrm{~g} / \mathrm{L}\end{array}$ & sample, $g$ & $\begin{array}{l}\text { concentration, C } \\
\text { g/L }\end{array}$ & $\mathrm{A}, \mathrm{mg} / \mathrm{g}$ & rate, $\%$ \\
\hline \multirow[t]{3}{*}{ Activated carbon } & \multirow{3}{*}{0.59} & 2 & 0.08 & 25.5 & 86.4 \\
\hline & & 3 & 0.0028 & 19.6 & 99.5 \\
\hline & & 4 & 0.00125 & 14.7 & 99.8 \\
\hline
\end{tabular}

Adsorption of $\mathrm{Fe}^{2+}$ in time on cellulose-contained carbonaceous material hazelnut shell (obtained at $850^{\circ} \mathrm{C}$, in small size reactor), walnut shell (obtained at $750^{\circ} \mathrm{C}$ ), factorymade activated carbon.

For the experiment was taken $1 \mathrm{~g}$ of each carbonaceous material - walnut shells, hazelnut shells and, for comparison, factory-made activated carbon. Then $100 \mathrm{ml} 0.01 \mathrm{M}$ solution of ferric sulfate $\left(\mathrm{FeSO}_{4} \cdot 7 \mathrm{H}_{2} \mathrm{O}\right)$ was added to $1 \mathrm{~g}$ of each material and stirred on a magnetic stirrer for 5, 10, 20, 30, 60, 90 and 120 minutes. The solutions were filtered and the concentration of residual ferric ions in the filtrate was measured using Zuzi spectrophotometer 4201/50. The results are shown in Table 18.

Table 18. Concentrations (initial $\mathrm{C}_{0}$ and final $\mathrm{C}$ ) and adsorption values $\left(\mathrm{A}, \mathrm{mg} / \mathrm{g}\right.$ ) of $\mathrm{Fe}^{++}$ions after delay time (with stirring) in solution of the various carbonaceous materials (hazelnut shells, walnut shells, activated carbon (fraction size 40 micron)), $\left(\mathrm{m}_{\text {sorb. }}=1 \mathrm{~g}, \mathrm{~V}_{\text {sol. }}=100 \mathrm{ml}, \mathrm{C}_{0}=0.56 \mathrm{~g} / \mathrm{L}, \mathrm{t}=25-27^{\circ} \mathrm{C}\right.$ ).

\begin{tabular}{|c|c|c|c|c|c|c|c|c|c|c|c|c|}
\hline \multirow{2}{*}{$\begin{array}{l}\text { Time } \\
\text { min }\end{array}$} & \multicolumn{4}{|c|}{$\begin{array}{l}\text { Walnut shells carbonaceous } \\
\text { material }\end{array}$} & \multicolumn{4}{|c|}{$\begin{array}{l}\text { Hazelnut shells carbonaceous } \\
\text { material }\end{array}$} & \multicolumn{4}{|c|}{$\begin{array}{l}\text { Factory-made activated } \\
\text { carbon }\end{array}$} \\
\hline & $\begin{array}{l}\mathrm{C}_{0}, \\
\mathrm{~g} / \mathrm{L}\end{array}$ & $\begin{array}{l}\mathrm{C}, \\
\mathrm{g} / \mathrm{L}\end{array}$ & $\begin{array}{l}\text { A, } \\
\mathrm{mg} \\
\mathrm{g}\end{array}$ & $\begin{array}{l}\text { Purificatio } \\
\text { n rate, } \%\end{array}$ & $\begin{array}{l}\mathrm{C}_{0}, \\
\mathrm{~g} / \mathrm{L}\end{array}$ & $\begin{array}{l}\mathrm{C}, \\
\mathrm{g} / \mathrm{L}\end{array}$ & $\begin{array}{l}\mathrm{A}, \\
\mathrm{mg} / \\
\mathrm{g}\end{array}$ & $\begin{array}{l}\text { Purificatio } \\
\text { n rate, } \%\end{array}$ & $\begin{array}{l}\mathrm{C}_{0}, \\
\mathrm{~g} / \mathrm{L}\end{array}$ & $\begin{array}{l}C, \\
g / L\end{array}$ & $\begin{array}{l}\mathrm{A}, \\
\mathrm{mg} / \\
\mathrm{g}\end{array}$ & $\begin{array}{l}\text { Purifica } \\
- \\
\text { tion } \\
\text { rate, \% }\end{array}$ \\
\hline 5 & \multirow{4}{*}{$\begin{array}{l}0.5 \\
6\end{array}$} & $\begin{array}{l}0.4 \\
1\end{array}$ & 15 & 26.7 & \multirow{4}{*}{$\begin{array}{l}0.5 \\
6\end{array}$} & $\begin{array}{l}0.5 \\
4\end{array}$ & 2 & 3.6 & \multirow{4}{*}{$\begin{array}{l}0.5 \\
6\end{array}$} & $\begin{array}{l}0.3 \\
7\end{array}$ & 19 & 33.9 \\
\hline 10 & & $\begin{array}{l}0.3 \\
9\end{array}$ & 17 & 30.3 & & $\begin{array}{l}0.5 \\
0\end{array}$ & 6 & 10.7 & & $\begin{array}{l}0.3 \\
3\end{array}$ & 23 & 41.1 \\
\hline 20 & & $\begin{array}{l}0.3 \\
7\end{array}$ & 19 & 33.9 & & $\begin{array}{l}0.4 \\
9\end{array}$ & 7 & 12.5 & & $\begin{array}{l}0.3 \\
2\end{array}$ & 24 & 42.9 \\
\hline 30 & & $\begin{array}{l}0.3 \\
3\end{array}$ & 23 & 41.1 & & $\begin{array}{l}0.4 \\
9\end{array}$ & 7 & 12.5 & & $\begin{array}{l}0.3 \\
0\end{array}$ & 26 & 46.4 \\
\hline
\end{tabular}




\begin{tabular}{|c|c|c|c|c|c|c|c|c|c|}
\hline 60 & $\begin{array}{l}0.3 \\
1\end{array}$ & 25 & 44.6 & $\begin{array}{l}0.4 \\
9\end{array}$ & 7 & 12.5 & $\begin{array}{l}0.2 \\
6\end{array}$ & 30 & 53.6 \\
\hline 90 & $\begin{array}{l}0.2 \\
8\end{array}$ & 28 & 50.0 & $\begin{array}{l}0.4 \\
7\end{array}$ & 9 & 16.1 & $\begin{array}{l}0.2 \\
4\end{array}$ & 32 & 57.1 \\
\hline 120 & $\begin{array}{l}0.2 \\
9\end{array}$ & 27 & 48.2 & $\begin{array}{l}0.5 \\
0\end{array}$ & 6 & 10.7 & $\begin{array}{l}0.2 \\
5\end{array}$ & 31 & 55.0 \\
\hline
\end{tabular}

Effect of $\mathrm{pH}$ on the adsorption of $\mathrm{Fe}^{2+}$ ions on the cellulose-contained carbonaceous material

Table 19. Adsorption of $\mathrm{Fe}^{2+}$ ions at different $\mathrm{pH}$ on various carbonaceous materials (fraction size 50 micron $),\left(\mathrm{m}_{\text {sorb. }}=1 \mathrm{~g} ., \mathrm{V}_{\text {sol. }}=100 \mathrm{ml}, \mathrm{C}_{0}=0.56 \mathrm{~g} / \mathrm{L}, \tau=90 \mathrm{~min}, \mathrm{t}=25-27^{\circ} \mathrm{C}\right)$.

\begin{tabular}{|c|c|c|c|c|c|c|c|c|c|}
\hline \multirow{2}{*}{$\mathrm{pH}$} & \multicolumn{3}{|c|}{$\begin{array}{l}\text { Carbonaceous material of } \\
\text { hazelnut shells }\end{array}$} & \multicolumn{3}{|c|}{$\begin{array}{l}\text { Carbonaceous material of } \\
\text { walnut shells }\end{array}$} & \multicolumn{3}{|c|}{ Activated carbon } \\
\hline & $\mathrm{C}_{0}, \mathrm{~g} / \mathrm{L}$ & $\mathrm{C}, \mathrm{g} / \mathrm{L}$ & $\mathrm{A}, \mathrm{mg} / \mathrm{g}$ & $\mathrm{C}_{0}, \mathrm{~g} / \mathrm{L}$ & $\mathrm{C}, \mathrm{g} / \mathrm{L}$ & $\mathrm{A}, \mathrm{mg} / \mathrm{g}$ & $\mathrm{C}_{0}, \mathrm{~g} / \mathrm{L}$ & $\mathrm{C}, \mathrm{g} / \mathrm{L}$ & $\begin{array}{l}\mathrm{A}, \\
\mathrm{mg} / \mathrm{g}\end{array}$ \\
\hline 2 & \multirow{4}{*}{0.56} & 0.56 & 0 & \multirow{4}{*}{0.56} & 0.56 & 0 & \multirow{4}{*}{0.56} & 0.55 & 1 \\
\hline 3 & & 0.31 & 25 & & 0.51 & 5 & & 0.26 & 30 \\
\hline 4 & & 0.30 & 26 & & 0.46 & 10 & & 0.26 & 30 \\
\hline 5 & & 0.37 & 19 & & 0.56 & 0 & & 0.29 & 25 \\
\hline
\end{tabular}

\section{Adsorption of ferric ions on solution of different concentrations.}

For the experiment $1 \mathrm{~g}$ of each carbonaceous material was taken - hazelnut shells (obtained at $850^{\circ} \mathrm{C}$ ), walnut shells (obtained at $750^{\circ} \mathrm{C}$ ), and factory-made activated carbon, grade A. To each amount was added solution of ferric sulfate $\left(\mathrm{FeSO}_{4} \cdot 7 \mathrm{H}_{2} \mathrm{O}\right)$ of various concentrations, in particular $0.01 \mathrm{M}, 0.02 \mathrm{M}$ and $0.005 \mathrm{M}$. Stirring was carried out on a magnetic stirrer during 90 minutes. The experiment was realized at room temperature $\left(25-27^{\circ} \mathrm{C}\right)$. The solutions were filtered and the concentration of residual ferric ions in the filtrate was measured using Zuzi spectrophotometer 4201/50. The results are shown in Table 20. 
Table 20. Concentrations (initial $\mathrm{C}_{0}$ and final $\mathrm{C}$ ) and adsorption values $(\mathrm{A}, \mathrm{mg} / \mathrm{g}$ ) of ferric ions after delay (with stirring) in solution of different molarity of adsorbents obtained from carbonaceous material of activated carbon, hazelnut shells, walnut shells (fraction size 40 micron), $\left(\mathrm{m}_{\text {sorb. }}=1 \mathrm{~g} ., \mathrm{V}_{\text {sol. }}=100 \mathrm{ml}, \tau=90\right.$ $\left.\min , \mathrm{t}=25-27^{\circ} \mathrm{C}\right)$.

\begin{tabular}{|c|c|c|c|c|c|c|c|c|c|c|c|c|}
\hline \multirow{2}{*}{$\begin{array}{l}\text { Mo- } \\
\text { larity } \\
\text { M }\end{array}$} & \multicolumn{4}{|c|}{$\begin{array}{l}\text { Hazelnut shells carbonaceous } \\
\text { material }\end{array}$} & \multicolumn{4}{|c|}{$\begin{array}{l}\text { Walnut shells carbonaceous } \\
\text { material }\end{array}$} & \multicolumn{4}{|c|}{$\begin{array}{l}\text { Factory-made } \\
\text { carbon }\end{array}$} \\
\hline & $\begin{array}{l}\mathrm{C}_{0} \\
\mathrm{~g} / \mathrm{L}\end{array}$ & $\mathrm{C}, \mathrm{g} / \mathrm{L}$ & $\begin{array}{l}\mathrm{A}, \\
\mathrm{mg} / \\
\mathrm{g}\end{array}$ & $\begin{array}{l}\text { Purifi- } \\
\text { cation } \\
\text { rate, } \\
\%\end{array}$ & $\begin{array}{l}\mathrm{C}_{0} \\
\mathrm{~g} / \mathrm{L}\end{array}$ & $\begin{array}{l}\mathrm{C} \\
\mathrm{g} / \mathrm{L}\end{array}$ & $\begin{array}{l}\mathrm{A}, \\
\mathrm{mg} \\
/ \mathrm{g}\end{array}$ & $\begin{array}{l}\text { Purifi- } \\
\text { cation } \\
\text { rate, } \\
\%\end{array}$ & $\begin{array}{l}\mathrm{C}_{0} \\
\mathrm{~g} / \mathrm{L}\end{array}$ & $\begin{array}{l}\mathrm{C}, \\
\mathrm{g} / \mathrm{L}\end{array}$ & $\begin{array}{l}\mathrm{A}, \\
\mathrm{mg} / \\
\mathrm{g}\end{array}$ & $\begin{array}{l}\text { Purifi- } \\
\text { cation } \\
\text { rate, \% }\end{array}$ \\
\hline 0.01 & 0.56 & 0.27 & 29 & 51.8 & 0.56 & 0.36 & 20 & 35.7 & 0.56 & 0.25 & 31 & 55.4 \\
\hline 0.02 & 1.16 & 0.76 & 40 & 34.5 & 1.16 & 0.96 & 20 & 17.2 & 1.16 & 0.88 & 28 & 24.1 \\
\hline 0.005 & 0.29 & 0.019 & 27.1 & 93.4 & 0.29 & 0.09 & 20 & 69 & 0.29 & 0.036 & $\begin{array}{l}25 \\
4\end{array}$ & 88 \\
\hline
\end{tabular}

1.Adsorption of lead ions on carbonaceous material of walnut shells (obtained at $\mathbf{t}=750^{\circ} \mathrm{C}$ ).

Conclusion: Equilibrium concentration was established during 1-1.5 hours.

2. Effect of pH on the adsorption of lead ions on the carbonaceous material of walnut shells (obtained at $\mathrm{t}=750^{\circ} \mathrm{C}$ ).

Conclusion: The adsorbent obtained from walnut shells shows good adsorption capacity when $\mathrm{pH}=5$.

3. Effect of temperature on the adsorption of lead ions on the carbonaceous material of walnut shells (obtained at $750^{\circ} \mathrm{C}$ ).

Conclusion: the best adsorption is achieved at $25 \mathrm{C}^{0}$.

4. Adsorption of lead ions on various amounts of walnut shells carbonaceous material (obtained at $750^{\circ} \mathrm{C}$ ).

Conclusion: About $96 \%$ of lead ions can be removed from every $100 \mathrm{ml}$ of $0.01 \mathrm{M}$ solution in 5 minutes using $5 \mathrm{~g}$ of adsorbent.

\section{Adsorption of lead ions on lead solutions of different concentrations.}

Conclusions: 
a) The higher the concentration of the solution, the less time it takes to achieve high adsorption (although of a comparatively lower quality than in dilute solutions).

b) In dilute solutions ( $0.98 \mathrm{~g} / \mathrm{L}), 1 \mathrm{~g}$ of adsorbent can reduce the lead concentration by half from $100 \mathrm{ml}$ of solution.

\section{REFERENCES}

[1] Moore D, Ramamurti S (1987) Heavy metals in natural waters. M.: Mir, 286 p.

[2] Marsagishvili T.A., Kirillov S.A., Machavariani M.N. Some aspects of physical and chemical adsorption on surface of amorphous solid. Abstr. conf.: Combined and Hybrid adsorbents: Fundamentals and Applications. Kiev, Puscha-Voditsa, Ukraine 15-17 Sept. 2005, p. 17.

[3] Marsagishvili T.A., Kirillov S.A., Machavariani M.N., Ananiashvili N.Sh. et al (2007), Amorphous oxides of manganese as new sorbents of strontium ions. Chemistry and Ecology 1,87-91. Issue 23.

[4] Romanenko K, Bogdanovich N et al (2017) Obtaining of activated carbons by pyrolysis hydrolytic lignin., "Forestry Journal", №4, 162 https://cyberleninka.ru/article/v/poluchenie-aktivnyh-ugley-pirolizom-gidroliznogolignina

[5] Marsagishvili T., Ananiashvili N., Metreveli J., Kikabidze-Gachechiladze M., Machavariani M.,Tatishvili G., Tskhakaya E. and Khositashvili R., (2014), Applications of georgian zeolites for the extraction of useful components from natural and waste waters. Eur. Chem. Bull.,1,ISSN 2063-5346,102-103, Issue 3.

[6] Zhilina M.V., Karnozhitski P.V. (2012), The relevance of the study of carbonization process for obtaining of activated carbon with the aim of utilization of plant waste.

[7] Yuhe, Cao (2017), Activated Carbon Preparation and Modification for Adsorption. PhD Thesis, South Dakota State University

[8] Bezdenezhnikh L, Alekseeva T et al (2007) New adsorbents from plant waste for adsorption purification of vegetable oil. Visnik KDPY imeni Mikhaila Ostrogradskogo. Issue 5/2007 (46).

[9] Ekpete O, Marcus A, and Osi V. (2017) Preparation and Characterization of Activated Carbon Obtained from Plantain (Musa paradisiaca) Fruit Stem. Journal of Chemistry Volume , Article ID 8635615, 6 pages https://doi.org/10.1155/2017/8635615 
[10] Arjuman Banu S, Nagarani S et al.( 2016). Preparation of Low Cost Activated Carbon Adsorbents from Natural Sources. International Journal of Engineering Technology Science and Research IJETSR www.ijetsr.com ISSN 2394 - 3386 Volume 3, Issue 4 April, 2016

[11] Ghaedia M, Golestani A et al.(2014). Application of activated carbon as adsorbents for efficient removal of methylene blue: Kinetics and equilibrium study. Volume 20, Issue 4, 25 July 2014, pp. 2317-2324

[12] Moyo M, Chikazaza L, Chomunorwa B et all.(2013). Adsorption Batch Studies on the Removal of $\mathrm{Pb}(\mathrm{II})$ Using Maize Tassel Based Activated Carbon. Hindawi Publishing Corporation Journal of Chamistry Volume 2103, Article ID 508934, 8 pages

[13] United States Patent and Trademark Office, patent US 9,663,662 B1.

[14] Method for obtaining sorbents from waste containing plastics and cellulose. Patent application, \# AP 2019 15030. 25.03.2019 (Patent is under consideration).

[15] Smirnov A, (1982) Sorption purification of water. Leningrad "Khimia", 1982, p. 188. 